\title{
Global phylogeography of the dusky shark Carcharhinus obscurus: implications for fisheries management and monitoring the shark fin trade
}

\author{
Martin T. Benavides ${ }^{1}$, Rebekah L. Horn ${ }^{2}$, Kevin A. Feldheim ${ }^{3}$, Mahmood S. Shivji ${ }^{2}$, \\ Shelley C. Clarke ${ }^{4}$, Sabine Wintner ${ }^{5}$, Lisa Natanson ${ }^{6}$, Matias Braccini ${ }^{7}$, \\ Jessica J. Boomer ${ }^{8}$, Simon J. B. Gulak ${ }^{9}$, Demian D. Chapman ${ }^{1, *}$ \\ ${ }^{1}$ Institute for Ocean Conservation Science \& School of Marine and Atmospheric Science, Stony Brook University, \\ Stony Brook, New York 11794, USA \\ ${ }^{2}$ Guy Harvey Research Institute and Save Our Seas Shark Center, Nova Southeastern University Oceanographic Center, \\ Dania Beach, Florida 33004, USA \\ ${ }^{3}$ Field Museum, Pritzker Laboratory for Molecular Systematics and Evolution, 1400 South Lake Shore Drive, Chicago, \\ Illinois 60605, USA \\ ${ }^{4}$ Oceanic Fisheries Programme, Secretariat of the Pacific Community, BPD5 CEDEX, Noumea 98848, New Caledonia \\ ${ }^{5}$ KwaZulu-Natal Sharks Board, Private Bag 2, Umhlanga Rocks 4320 and Biomedical Resource Unit, \\ University of KwaZulu-Natal, Durban 4000, South Africa \\ ${ }^{6}$ NOAA Fisheries Service, 28 Tarzwell Dr., Narragansett, Rhode Island 02882, USA \\ ${ }^{7}$ Fisheries Centre, The University of British Columbia, Vancouver, British Columbia V6T1Z4, Canada \\ ${ }^{8}$ Department of Biological Sciences, Macquarie University, Sydney, New South Wales 2109, Australia \\ ${ }^{9}$ NOAA Fisheries Service, Southeast Fisheries Science Center, 3500 Delwood Beach Road, Panama City, Florida 32408, USA
}

\begin{abstract}
Genetic stock structure information is needed to delineate management units and monitor trade in sharks, many of which are heavily exploited and declining. The dusky shark Carcharhinus obscurus is a large apex predator that is sought after for its fins and is considered highly susceptible to overexploitation. The International Union for the Conservation of Nature (IUCN) classifies this species as 'Vulnerable' globally and 'Endangered' in the northwest Atlantic. We make the first assessment of global stock structure of C. obscurus by analyzing part of the mitochondrial control region (mtCR) in 255 individuals sampled from 8 geographically dispersed locations. We found $25 \mathrm{mtCR}$ haplotypes and rejected a null hypothesis of panmixia (analysis of molecular variance, $\Phi_{\mathrm{ST}}=$ $0.55, \mathrm{p}<0.000001$ ), detecting significant differentiation between 3 management units: US Atlantic (USATL), South Africa (SAF), and Australia (AUS). We also found preliminary evidence of population structure between the USATL and southwest Atlantic (Brazil). There were no shared haplotypes between the western Atlantic and Indo-Pacific. These analyses suggest that replenishment of the collapsed USATL management unit via immigration of females from elsewhere is unlikely. Mixed stock analysis (MSA) simulations show that reconstruction of the relative contributions of USATL, SAF, and AUS management units to the Asian fin trade is possible using these mtCR sequences. We suggest avenues for obtaining samples to conduct MSA of the shark fin trade, which could enhance management of dusky sharks and other species that are exploited for their fins.
\end{abstract}

KEY WORDS: Mitochondrial DNA $\cdot$ Phylogeography $\cdot$ Conservation $\cdot$ Mixed stock analysis Resale or republication not permitted without written consent of the publisher

\section{INTRODUCTION}

Many shark populations worldwide are experiencing intense fishing pressure, largely fueled by the high prices paid for their fins for use in the Asian delicacy, shark fin soup (Bonfil 1994, Rose 1996, Clarke et al. 2006a,b, Cortés et al. 2006). Genetic studies of coastally oriented shark species indicate that gene flow (i.e. movement and reproductive mixing) is often highly restricted between regions, which means that 
intensively fished populations are vulnerable to localized collapse and are unlikely to recover through immigration (e.g. Duncan et al. 2006, Keeney \& Heist 2006, Stow et al. 2006, Schultz et al. 2008, Chabot \& Allen 2009, Chapman et al. 2009). This highlights the need for monitoring of shark landings on a stockspecific basis, which has been internationally recognized as a pressing need for global shark conservation efforts (FAO 2000, ICCAT 2005).

Population genetic studies have shown that sexbiased gene flow is common in sharks (Pardini et al. 2001, Schultz et al. 2008, Portnoy et al. 2010). Maternally inherited mitochondrial loci typically exhibit significantly greater structure than bi-parentally inherited nuclear loci, probably because female sharks often exhibit philopatry to specific coastal areas for parturition (Feldheim et al. 2004). Using mitochondrial DNA to help establish management units for sharks is therefore important because management units delineated in this way at least represent discrete pools of breeding females that are associated with a specific geographic area for reproduction (Moritz 1994). Because of the high levels of structure typically observed and its maternal mode of inheritance, mitochondrial DNA sequence data can provide information on the natal population of origin for shark products in trade (Chapman et al. 2009).

The dusky shark Carcharhinus obscurus is among the most vulnerable of all sharks to overexploitation, due to its extremely late age at maturity (17-23 yr), small litter sizes (3-14 offspring per litter) and $3 \mathrm{yr}$ reproductive cycle including a 24 mo gestation period (Last \& Stevens 1994, Natanson et al. 1995, Simpfendorfer et al. 2002, Romine et al. 2009). Dusky sharks are potentially important apex predators and have a widespread but discontinuous distribution in warm temperate and subtropical regions, with major population centers along the east and Gulf of Mexico coasts of North America, southern Africa, and Australia (Musick et al. 2007). Their fins are sorted by Chinese dealers under the trade category 'Hai hu,' and it has been estimated that 150000 to 750000 individuals are harvested annually to supply the fin trade (Clarke et al. 2006b). The contribution of particular stocks to these landings remains unknown, making it difficult to determine if this level of global harvest is sustainable.

Dusky sharks have experienced serious population declines in some regions, arguing against the sustainability of recent harvest levels. Along the US east coast and Gulf of Mexico, for example, a recent stock assessment has shown declines of over $80 \%$ with respect to virgin biomass (Cortés et al. 2006). Similarly, overfishing in Australia has led to a decline in recruitment (McAuley et al. 2005). Overall, dusky sharks are assessed as Vulnerable A2bd globally by the International Union for the Conservation of Nature (IUCN) (www.iucnredlist.org/ apps/redlist/details/3852/0), while the US east coast and Gulf of Mexico population is assumed by IUCN assessors to be a single distinct unit and is classified as Endangered (Musick et al. 2007). Dusky sharks have been prohibited from the landings of US fisheries since 2000, although they are still caught incidentally and their fins are sometimes traded illegally (Romine et al. 2009, Shivji 2010). They are also currently listed as a Species of Concern for potential listing under the US Endangered Species Act.

It is possible that gene flow occurs over a wide geographic area in dusky sharks, perhaps making them more similar to pelagic fish than coastal sharks in terms of their population structure (e.g. Garber et al. 2005, McDowell et al. 2007). For example, tagging studies have shown that dusky sharks undertake long coastal migrations related to seasonal temperature changes, with individual movements of up to $3800 \mathrm{~km}$ recorded along continental coastlines (Davies \& Joubert 1967, Kohler 1996, Hussey et al. 2009). They also use pelagic habitats off the continental shelf from a very early age (Beerkircher et al. 2002), which could mean that oceanic expanses are not a serious barrier to gene flow. Lastly, life history parameters such as growth rate, size and age at maturity, and longevity are very similar among dusky sharks in the western Atlantic (USA), western Indian (South Africa), and eastern Indian Ocean (western Australia; Simpfendorfer et al. 2002), suggesting that they may represent a single panmictic stock. Ovenden et al. (2009) reported possible differences in mitochondrial haplotype frequencies between Australian and Indonesian dusky sharks, but their sample sizes were too small to be conclusive.

The primary objective of this study was to test the 'global panmixia' hypothesis for dusky sharks, using maternally inherited mitochondrial control region (mtCR) sequence data. We aimed to identify any genetic discontinuities between regional collections that would help establish robust management units for this vulnerable species. Our particular focus was to assess connectivity between the collapsed, Endangered US east coast and Gulf of Mexico population(s) and other regions. The second objective of this study was to assess whether the genetic differences between any management units we found are large enough to be able to use mixed stock analysis (MSA) to reconstruct their relative contributions to the Asian fin trade.

\section{MATERIALS AND METHODS}

In total, 255 dusky sharks were sampled for tissue, collected from 8 globally distributed sampling areas (Fig. 1): US east coast (USEC), US Gulf of Mexico (USGOM), Brazil (BRA), South Africa (SAF), west Aus- 
tralia (WAUS), east Australia (EAUS), Taiwan (TAI), and Peru (PER). Tissue samples were obtained by a combination of fishery sampling (both recreational and commercial), research cruises, and beach meshing captures. Most of the individuals sampled were juveniles (e.g. mean \pm SD total lengths were: USEC, $126 \pm$ $26 \mathrm{~cm}$; SAF, $128 \pm 51 \mathrm{~cm}$; WAUS, $110 \pm 15 \mathrm{~cm})$. Collections were built from a large number of independent sampling events conducted over several years. The only exception to this was that 10 of these samples were taken from dried fins obtained from several visits to 2 different shark fin dealers in Hong Kong (Clarke et al. 2006a,b), who stated that the fins came from Brazilian suppliers. After verifying their species identity (see next paragraph), we analyzed these samples, assuming the animals were caught in Brazil, but stress that findings related to them are tentative until such time as additional dusky sharks directly sampled in Brazil become available. All tissues were preserved in 95\% reagent grade ethanol and stored at room temperature.
Tissue types included fins (wet and dried), muscle, and soft tissue excised from vertebrae that had been archived for age and growth studies. Total genomic DNA was extracted from $25 \mathrm{mg}$ of tissue using the DNeasy ${ }^{\circledR}$ Blood and Tissue kit (Qiagen) following the manufacturer's protocol, with some adjustments of final elution volumes based on tissue type. Samples from fins generally contained a higher DNA concentration than the other tissues and were eluted into a final volume of $300 \mu \mathrm{l}$, while muscle and vertebrae-soft tissue extractions were eluted in $150 \mu \mathrm{l}$. Genomic DNA was checked for quality and approximate quantity on a $0.8 \%$ agarose gel run at $60 \mathrm{~V}$ for $\sim 45 \mathrm{~min}$.

Dusky sharks are sometimes confused with the closely related carcharhinid sharks, so we made efforts to genetically verify that all samples used in this study were the correct species, even if they had been identified as such by experienced biologists. To achieve this, we tested all samples with the species-diagnostic polymerase chain reaction (PCR) assay of Pank et al. (2001)

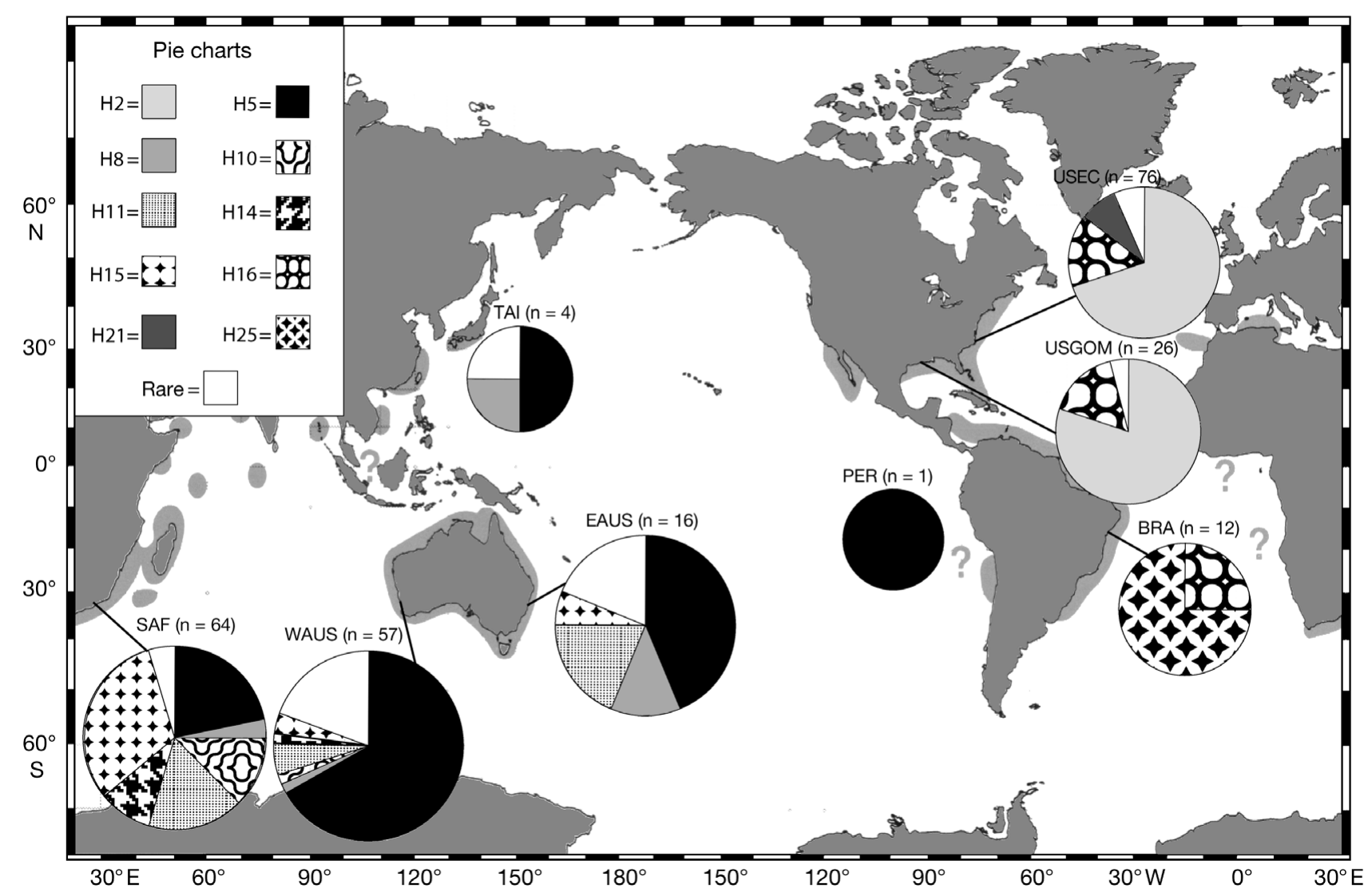

Fig. 1. Carcharhinus obscurus. Mitochondrial control region (mtCR) haplotype frequencies obtained from samples collected across the global distribution of the dusky shark: US east coast (USEC), US Gulf of Mexico (USGOM), Brazil (BRA), South Africa (SAF), west Australia (WAUS), east Australia (EAUS), Taiwan (TAI), and Peru (PER). Known distribution is in light gray, '?' represents unconfirmed parts of distribution. Note that 10 of 12 samples putatively from Brazil were obtained from Hong Kong-based fin dealers who had both indicated that the fins had been purchased directly from Brazil. Haplotype codes in the key correspond to codes in Fig. 2, except that haplotypes that occurred at low frequency are all coded as 'Rare.' Map is adapted from Last 
and also sequenced the entire internal transcribed spacer (ITS2) locus in a random set of individuals ( $40 \%$ of specimens, including all of the putative Brazilian individuals). PCR was used to amplify the mtCR from all samples. Reactions were carried out in $50 \mu \mathrm{l}$ volumes containing $1 \mu \mathrm{l}$ of genomic DNA, $1 \times$ PCR buffer (Qiagen), a total of $40 \mu \mathrm{M}$ deoxynucleoside triphosphates (dNTPs), $12.5 \mathrm{pmol}$ of each of the primers Pro-L (5'-AGG GRA AGG AGG GTC AAA CT3', Keeney et al. 2003) and 12S (5'-AAG GCT AGG ACC AAA CCT-3'; Keeney et al. 2003), and 1 unit of HotStar Taq ${ }^{\mathrm{TM}}$ DNA Polymerase (Qiagen). PCR was performed in a LabnetMultigene TC9600-G thermocycler for 35 cycles of $1 \mathrm{~min}$ at $95^{\circ} \mathrm{C}, 1 \mathrm{~min}$ at $65^{\circ} \mathrm{C}$, and 2 min at $72^{\circ} \mathrm{C}$, followed by a final extension step of $72^{\circ} \mathrm{C}$ for $10 \mathrm{~min}$. PCR products were purified using Exonuclease I and shrimp alkaline phosphatase according to the manufacturer's protocol (USB). Dye termination sequencing was performed using the Pro-L forward primer. Cycle sequencing reactions were performed in a Bio-RAD Dyad thermocycler for 25 cycles of $96^{\circ} \mathrm{C}$ for $10 \mathrm{~s}, 50^{\circ} \mathrm{C}$ for $5 \mathrm{~s}$, and $60^{\circ} \mathrm{C}$ for $4 \mathrm{~min}$. Sequencing reactions were precipitated with ethanol and $125 \mathrm{mM}$ EDTA and run on an ABI 3730 DNA Analyzer.

Sequences were validated by eye in the program Chromas 2.33 (www.technelysium.com.au) and aligned and trimmed in the program GeneDoc (www.nrbsc. org/gfx/genedoc/), resulting in a partial sequence of the $5^{\prime}$ end of the mtCR that was $~ 558 \mathrm{bp}$ in length. All distinct haplotypes were verified by sequencing them in both the forward and reverse direction. A maximum parsimony haplotype network was drawn in TCS 1.21 at the $95 \%$ confidence interval to show the evolutionary relationships between haplotypes (Clement et al. 2000). Genetic diversity indices for each sampling region, as well as overall diversity indices, were calculated in DnaSP 4.0 (Rozas et al. 2003).

Our primary study objective was to test the null hypothesis that there is no genetic differentiation across our entire sampling region. We used analysis of molecular variance (AMOVA) run in Arlequin 3.1 (Excoffier et al. 1992, Schneider et al. 2000) to partition genetic variance within and among populations and then calculate the fixation index $\Phi_{\mathrm{ST}}$. We used the Tamura Nei substitution model to calculate genetic distances between haplotypes because it had the highest log likelihood score of all models available in Arlequin 3.1 according to jModeltest (Posada 2008).

Prior to conducting the global AMOVA, we conducted a smaller one involving the 2 Australian populations on their own (i.e. EAUS and WAUS). Our rationale for doing this was that only a small number of mtCR sequences were available to us from dusky sharks collected in EAUS $(\mathrm{n}=16)$ but a published study (Ovenden et al. 2009) provided 7 additional ones, albeit involving a smaller mtCR sequence (375 bp). Rather than using these 7 additional samples in the global AMOVA and trimming all of our sequences from 558 to $375 \mathrm{bp}$, we trimmed our WAUS and EAUS sequences and combined them with EAUS sequences from Ovenden et al. (2009) (GenBank accession number of their base sequence is FJ161688). We then run an AMOVA with 1 group containing the 2 populations (i.e. WAUS $\mathrm{N}=57, \mathrm{EAUS}=23 ; 375 \mathrm{bp}$ of sequence). This analysis indicated a lack of structure within Australia $\left(\Phi_{\mathrm{ST}}=0.015, \mathrm{p}>0.17\right)$ and provided justification for pooling our full sequences (i.e. $558 \mathrm{bp}$ ) from EAUS and WAUS into 1 'Australia' (AUS) population for the global AMOVA. The global AMOVA therefore included 1 group of 4 populations: USEC $(\mathrm{n}=76)$, USGOM $(n=25), \operatorname{SAF}(n=64)$, and AUS $(n=73)$. We also calculated pairwise $\Phi_{\mathrm{ST}}$ between all 4 populations and tested their significance with 10000 permutations of the sequence data.

A second study objective was to demonstrate that the amount of mtCR differentiation we observed between defined management units (see 'Results') was large enough for mixed stock analysis to be capable of estimating their relative contributions to dusky shark products (e.g. fins) in trade. To achieve this, we ran simulations in a commonly used mixed stock analysis (MSA) program (Statistics Program for Analyzing Mixtures: SPAM 3.7b; www.cf.adfg.state. ak.us/geneinfo/research/genetics/genetics.php). The SPAM program randomly resampled the baseline mitochondrial haplotype frequency of each management unit delineated in this study to construct mixtures of 100 'fins' with a specified contribution from each one. The program then used maximum likelihood (1000 iterations) to reassign each 'fin' in the mixture back to its most probable management unit of origin and thus reconstructed the entire contribution of each one to the 'fin' mixture. The level of concordance between the mean estimated contributions of each management unit to the mixture and the known, user-specified contributions assesses the identifiability of management units using this approach. We ran multiple simulations using a range of userspecified contributions from each management unit which we defined in our phylogeographic study.

\section{RESULTS}

All 255 dusky sharks were genetically verified using species-specific PCR and/or ITS2 sequences (data not shown). Partial mtCR sequences were obtained from all of them (GenBank accession numbers HQ853257 [Haplotype 1] to HQ853281[Haplotype 25]). The $558 \mathrm{bp}$ segment of the $5^{\prime}$ end of the mtCR obtained was com- 
posed of $20.57 \%$ cytosine, $37.59 \%$ thymine, $30.68 \%$ adenine, and $11.16 \%$ guanine. There were 22 polymorphic sites among the 255 individuals, composed of 16 transition mutations, 5 transversions, and 2 insertions/deletions (indels).

Of the 25 total haplotypes in the overall sample set, 10 were found in the western Atlantic (i.e. US east coast, US Gulf of Mexico, and Brazil samples), and were endemic to this region. Assuming that the Hong Kong dealers provided accurate provenance information about their 'Brazil' fins, it appears that there are major haplotype frequency differences between the southwest Atlantic and the USA (Figs. $1 \& 2$ ). The putative Brazil sample $(n=12)$ consisted of the second most common US haplotype ( $\mathrm{n}=3$, haplotype 16 from Fig. 2) and a more common haplotype ( $\mathrm{n}=9$, haplotype 25 from Fig. 2) that was not seen anywhere else in the world but is intermediate to western Atlantic and IndoPacific haplotypes (Fig. 2). Eight haplotypes were found in South Africa (2 endemic to this location in our dataset), and 13 were found in Australia ( 7 endemic,
Figs. 1 \& 2, Table 1). Six haplotypes were shared between Australia and South Africa. We also obtained partial mtCR sequences from dusky sharks sampled in Taiwan $(\mathrm{N}=4)$ and Peru $(\mathrm{n}=1)$ that amounted to 3 haplotypes, all of which were also found in Australia and/or South Africa. Overall haplotype diversity (h) of the global sample was $0.84 \pm 0.03$, and nucleotide diversity $(\pi)$ was $0.005 \pm 0.0005$ (Table 2 ). We reiterate that because of the small sample sizes, mtCR sequences obtained from Peru and Taiwan were not included in further analyses of population structure. We also elected not to include Brazil $(n=12)$ in the subsequent quantitative analyses of population structure, given that most of the samples were obtained from Asian fin dealers rather than having been taken directly from wild-captured animals.

We reject the hypothesis that dusky sharks are globally panmictic (AMOVA global $\Phi_{\mathrm{ST}}=0.55, \mathrm{p}<$ $0.000001 ;$ Table 3$)$. Pairwise $\Phi_{\mathrm{ST}}$ values between collections revealed at least 3 significantly differentiated groups: US Atlantic (USATL; comprised of USEC and

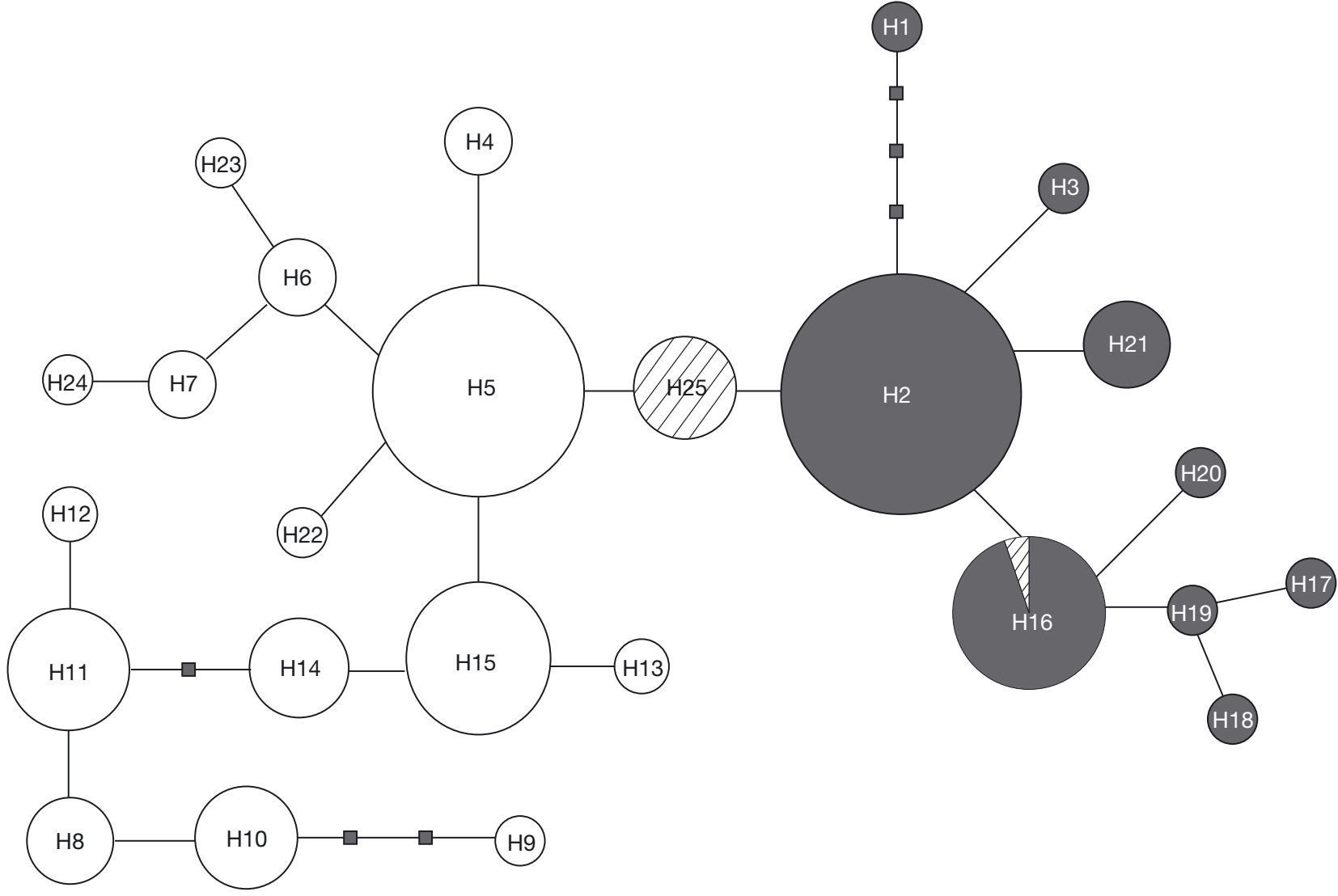

Fig. 2. Carcharhinus obscurus. Mitochondrial control region (mtCR) haplotype network (95\% confidence), with individual haplotypes denoted by the number in each circle. The size of the circle is proportional to the frequency of the haplotype in the global sample. Solid circles represent haplotypes found in the USA. Open circles represent haplotypes observed in the Indo-Pacific. Striped circles or fractions of circles represent haplotypes directly collected or putatively originating from Brazil. Small squares represent inferred mutational steps between haplotypes 
Table 1. Carcharhinus obscurus. Global dusky shark haplotype frequency distribution with designated haplotype number (Hap. no.) and sampling region. Cells contain the number of times the designated haplotype was observed in a sampling region. WAUS: west Australia; EAUS: east Australia; BRA: Brazil; USGOM: US Gulf of Mexico; USEC: US east coast; PER: Peru; SAF: South Africa; TAI: Taiwan

\begin{tabular}{|lccccccccccccccccccccccccc|}
\hline $\begin{array}{l}\text { Sampling } \\
\text { region }\end{array}$ & 1 & 2 & 3 & 4 & 5 & 6 & 7 & 8 & 9 & 10 & 11 & 12 & 13 & 14 & 15 & 16 & 17 & 18 & 19 & 20 & 21 & 22 & 23 & 24 & 25 \\
\hline WAUS & 0 & 0 & 0 & 1 & 38 & 4 & 2 & 1 & 0 & 1 & 3 & 2 & 0 & 1 & 2 & 0 & 0 & 0 & 0 & 0 & 0 & 1 & 0 & 1 & 0 \\
EAUS & 0 & 0 & 0 & 2 & 7 & 0 & 0 & 2 & 0 & 0 & 3 & 0 & 0 & 0 & 1 & 0 & 0 & 0 & 0 & 0 & 0 & 0 & 1 & 0 & 0 \\
BRA & 0 & 0 & 0 & 0 & 0 & 0 & 0 & 0 & 0 & 0 & 0 & 0 & 0 & 0 & 0 & 3 & 0 & 0 & 0 & 0 & 0 & 0 & 0 & 0 & 9 \\
USGOM & 0 & 20 & 0 & 0 & 0 & 0 & 0 & 0 & 0 & 0 & 0 & 0 & 0 & 0 & 0 & 4 & 0 & 1 & 0 & 0 & 0 & 0 & 0 & 0 & 0 \\
USEC & 1 & 53 & 1 & 0 & 0 & 0 & 0 & 0 & 0 & 0 & 0 & 0 & 0 & 0 & 0 & 12 & 1 & 0 & 1 & 1 & 6 & 0 & 0 & 0 & 0 \\
PER & 0 & 0 & 0 & 0 & 1 & 0 & 0 & 0 & 0 & 0 & 0 & 0 & 0 & 0 & 0 & 0 & 0 & 0 & 0 & 0 & 0 & 0 & 0 & 0 & 0 \\
SAF & 0 & 0 & 0 & 0 & 14 & 0 & 0 & 2 & 1 & 8 & 11 & 0 & 2 & 6 & 20 & 0 & 0 & 0 & 0 & 0 & 0 & 0 & 0 & 0 & 0 \\
TAI & 0 & 0 & 0 & 0 & 2 & 0 & 1 & 1 & 0 & 0 & 0 & 0 & 0 & 0 & 0 & 0 & 0 & 0 & 0 & 0 & 0 & 0 & 0 & 0 & 0 \\
\hline
\end{tabular}

Table 2. Carcharhinus obscurus. Summary of sample size (n), number of haplotypes, haplotype diversity $(h)$, nucleotide diversity $(\pi)$, and coancestry coefficient $\left(\theta_{\mathrm{S}}\right)$ in all sampling regions in this study. Sampling region codes follow Table 1. Samples from Brazil, Peru, and Taiwan are not included in this table

\begin{tabular}{|lccccc|}
\hline $\begin{array}{l}\text { Sampling } \\
\text { region }\end{array}$ & $\mathrm{n}$ & Haplotypes & $h$ & $\pi$ & $\theta_{\mathrm{S}}$ \\
\hline WAUS & 57 & 12 & 0.55201 & 0.00266 & 2.17 \\
EAUS & 16 & 6 & 0.78333 & 0.00466 & 2.41 \\
USGOM & 25 & 3 & 0.34667 & 0.00089 & 0.79 \\
USEC & 76 & 8 & 0.48807 & 0.00121 & 1.64 \\
SAF & 64 & 8 & 0.81101 & 0.0037 & 1.49 \\
\hline
\end{tabular}

USGOM, pairwise $\Phi_{\mathrm{ST}}$ non-significant; Table 4), South Africa (SAF), and Australia (AUS). MSA simulation results for a hypothetical mixture of 100 'fins' in trade indicated sufficient differentiation in mtCR haplotype frequencies between the USATL, SAF, and AUS to allow for reasonably accurate reconstruction of each of their contributions (Table 5). Mean simulationrecovered contributions were consistently very close to the user-specified contributions, with a narrow deviation around the mean. MSA was generally less accurate in resolving the relative contributions of these groups to mixtures when their contributions were small $(\sim 5 \%)$, at least in the sense that the standard deviations of simulation-estimated contributions were quite large relative to the mean in these cases

Table 3. Global analysis of molecular variance $(\mathrm{p}<0.000001)$

\begin{tabular}{|lcccc|}
\hline $\begin{array}{l}\text { S-statistics } \\
\text { source of variation }\end{array}$ & df & $\begin{array}{c}\text { Sum of } \\
\text { squares }\end{array}$ & $\begin{array}{c}\text { Variance } \\
\text { components }\end{array}$ & $\begin{array}{c}\text { Percentage } \\
\text { of variation }\end{array}$ \\
\hline Among populations & 3 & 148.681 & 0.85492 & 55.46 \\
Within populations & 234 & 160.649 & 0.68653 & 44.54 \\
Total & 237 & 309.330 & 1.54145 & \\
Fixation index $\left(\Phi_{\mathrm{ST}}\right)$ & 0.55462 & & & \\
\hline
\end{tabular}

Table 4. Carcharhinus obscurus. Population differentiation among samples collected in 4 regions. Numbers below the diagonal show pairwise $\Phi_{\mathrm{ST}}$ values between sampling locations. Asterisks above the diagonal indicate pairwise $\Phi_{\mathrm{ST}}$ values that were significantly different from 0 ( $p<0.000001)$. USEC: US east coast, GOM: Gulf of Mexico, SAF: South Africa, AUS: Australia, ns: non-significant

\begin{tabular}{|lcccc|}
\hline $\begin{array}{l}\text { Sampling } \\
\text { region }\end{array}$ & USEC & GOM & SAF & AUS \\
\hline USEC & - & $\mathrm{ns}(\mathrm{p}>0.54)$ & $*$ & $*$ \\
GOM & -0.0089 & - & $*$ & $*$ \\
SAF & 0.68 & 0.63 & - & $*$ \\
AUS & 0.62 & 0.57 & 0.18 & - \\
\hline
\end{tabular}

(Table 5). However, as their contributions increased, the standard deviation tightened around the mean, suggesting that meaningful reconstructions will be possible for large fin mixtures.

\section{DISCUSSION}

Dusky sharks exhibit high mitochondrial control region genetic diversity on a global scale in terms of numbers of haplotypes (25) and haplotype diversity $(h=0.84 \pm 0.03)$. These values are within the range of those calculated for other large, globally-distributed sharks (Duncan et al. 2006, Keeney \& Heist 2006, Castro et al. 2007, Ahonen et al. 2009, Chabot \& Allen 2009, Schultz et al. 2008, Portnoy et al. 2010). In contrast, overall nucleotide diversity is among the lowest recorded for any large, globally-distributed shark $(\pi=0.005 \pm 0.0005$, Duncan et al. 2006, Keeney \& Heist 2006, Castro et al. 2007, Ahonen et al. 2009, Chabot \& Allen 2009, Schultz et al. 2008, Portnoy et al. 2010). The existence of a morphologically and genetically very similar 
Table 5. Carcharhinus obscurus. Mixed stock analysis (MSA) simulation results from Statistic Program for Analyzing Mixtures (SPAM) 3.7b (www.cf.adfg.state. ak.us/geneinfo/research/genetics/genetics.php). The table shows the level of concordance between the known management unit contributions ('user-specified') and mean management unit contributions reconstructed in SPAM ('reconstructed contributions'). The reconstructions are based on the haplotype frequencies obcular variance: US Atlantic (USATL), South Africa (SAF), and Australia (AUS)

\begin{tabular}{ll}
$\begin{array}{l}\text { User-specified } \\
\text { contributions (\%) }\end{array}$ & Reconstructed contributions (mean \pm SD, \%) \\
\hline 33 USATL, 33 SAF, 33AUS & $33.3 \pm 4.6$ USATL, 33.1 $\pm 6.9 \mathrm{SAF}, 33.6 \pm 6.6 \mathrm{AUS}$ \\
90 USATL, 5 SAF, 5 AUS & $90.1 \pm 3$ USATL, 5.03 $\pm 2.9 \mathrm{SAF}, 4.87 \pm 2.9 \mathrm{AUS}$ \\
5 USATL, 90 SAF, 5 AUS & $5.11 \pm 2.2$ USATL, 89.8 $\pm 4.8 \mathrm{SAF}, 5.06 \pm 4.5 \mathrm{AUS}$ \\
5 USATL, 5 SAF, 90 AUS & $5.15 \pm 2.2$ USATL, 5.23 $\pm 4.5 \mathrm{SAF}, 89.6 \pm 4.9 \mathrm{AUS}$
\end{tabular}
served in this study for the 3 management units we defined from analysis of mole-

Although dusky sharks in the US Atlantic, South Africa, and Australia have very similar vital rates (e.g. growth, age at maturity), we demonstrate that each of these populations is genetically differentiated and therefore at least semiautonomous. We hereafter refer to 3 management units for dusky sharks: US Atlantic (USATL), South Africa (SAF), and Australia (AUS). We stop short of calling these groups 'stocks' on the grounds that we would need to demonstrate differentiation at nuclear loci to do so. Nevertheless, each of the management units at least sibling species (Galapagos shark Carcharhinus galapagensis) indicates that the dusky shark is recently derived (Naylor 1992, Musick et al. 2004), which may explain why its nucleotide diversity is still relatively low. We also found that the Indo-Pacific populations in our dataset had higher genetic diversity than the western Atlantic populations, which is concordant with patterns seen in other sharks that are thought to have originated in the Indo-Pacific (Duncan et al. 2006, Keeney \& Heist 2006, Ahonen et al. 2009, Chapman et al. 2009).

We did not find evidence of differentiation between the USEC and USGOM dusky sharks, which is consistent with the findings for some other species of shark studied in this region (Heist et al. 1996, Chapman et al. 2009). The absence of structure here is supported by conventional tagging data from the National Marine Fisheries Service (NMFS), in which movements by individual dusky sharks of up to $3800 \mathrm{~km}$ (from the USEC to the Yucatán peninsula) are documented, and contemporary exchange between the USEC and USGOM appears to be quite common (Kohler 1996). The genetic and tagging data combined support the current US policy of assessing and managing a single stock of dusky sharks within this region. However, we cannot completely rule out that migratory female dusky sharks home back to their natal region of origin to breed, which could generate genetically distinct management units that could only be recognized by sampling neonates in their natal area or females undergoing parturition (e.g. see sampling design of Keeney et al. 2005). This may prove very difficult to resolve because youngof-the year dusky sharks are mobile and are found in coastal and even pelagic habitats as opposed to being concentrated in discrete estuarine nursery areas (Beerkircher et al. 2002). We also did not detect genetic differentiation between Australia's east (Pacific Ocean) and west (Indian Ocean) coasts, suggesting that gene flow also occurs around this coastline. represents a discrete pool of breeding females reproducing in a particular region that should be assessed and managed independently of one another. Robust barriers to gene flow (at least for females) clearly exist between these regions. We speculate that the large oceanic expanse separating these management units inhibits gene flow between them. It is also possible that extreme thermal barriers (e.g. the cold Benguela upwelling along the southwest coast of Africa and/or equatorial regions) inhibit gene flow, given that dusky sharks are centered in warm temperate as opposed to tropical or boreal latitudes (Musick et al. 2004).

We tentatively report qualitative evidence of population structure between dusky sharks in the USATL and Brazil, which parallels other large sharks (Schultz et al. 2008, Chapman et al. 2009). Interestingly, the most common putative Brazil haplotype in our sample (H25, Fig. 2) is intermediate to the USATL and Indo-Pacific haplotype clusters in our parsimony network, suggesting that the Atlantic coast of South America may have provided the historical connection between the western Atlantic and Indo-Pacific populations. Overall, our study indicates that the recovery of collapsed USATL dusky sharks is likely to rely on reproduction by surviving local females as opposed to replenishment from immigrant females from the neighboring southwest Atlantic or from the Indo-Pacific. More direct sampling tive findings.

The existence of at least 2 management units within Indo-Pacific dusky sharks is similar to several other large sharks that exhibit population structure between southern Africa and Australia (Pardini et al. 2001, Ahonen et al. 2009, Dudgeon et al. 2009). In some shark species, this structure occurs because the species is primarily neritic and gene flow has been minimal since population founding (Ahonen et al. 2009, Dudgeon et al. 2009). In white sharks Carcharodon carcharias, conin Brazil is necessary to validate (or refute) these tenta- 
temporary movement directly across the Indian Ocean is known to occur (Bonfil et al. 2005), but it is thought that female-mediated gene flow is restricted by homing of gravid females to their natal coastline of origin for parturition (Pardini et al. 2001). While gene flow is restricted between AUS and SAF dusky sharks, there is some haplotype sharing between them. This may reflect a lesser propensity for natal homing in female dusky sharks compared to white sharks, a low level of movement of individuals between regions, or incomplete lineage sorting, given the relatively recent radiation of this species (Naylor 1992, Musick et al. 2004). Gene flow between Australia and South Africa need not involve pelagic movement of dusky sharks directly across the Indian Ocean, as their Indo-Pacific distribution suggests they might occasionally move along the coasts of Africa and southeast Asia and then 'island hop' to Australia and vice versa (see distribution depicted in Fig.1).

Assessing the sustainability of shark fin harvests on a stock-specific basis is increasingly important for the conservation of widely-distributed sharks like the dusky. This is a daunting prospect, however, given the large number of active shark-fishing nations and the limited monitoring capacity of many of them (Dulvy et al. 2008). In contrast, the world's largest shark fin markets occur in a handful of Asian countries (Clarke et al. 2006a,b), which suggests that genetics-based MSA of fins in or on their way to these markets could be a more efficient way to estimate stock-specific shark fin landings (Chapman et al. 2009, Shivji 2010). MSA will be feasible when (1) genetic data can be obtained affordably from traded products, (2) genetic stock structure is robust and well documented, and (3) products in trade or in markets can be sampled in a representative manner. In reference to (1) and (2), the MSA simulations of the present study provide proof-of-concept that an affordably obtained partial mtCR sequence enables robust reconstruction of the contribution of at least 3 dusky shark management units to trade-derived fins. By extension, the contribution of these management units to other dusky shark products in trade should similarly be possible. Although we have robustly sampled most of the regions where dusky sharks are common, nuclear marker data and additional sampling efforts to define all management units and delineate their boundaries are now necessary so that MSA can be applied at its full potential.

As population genetic data accumulate for this and other shark species (e.g. Pardini et al. 2001, Ahonen et al. 2009, Duncan et al. 2006, Keeney \& Heist 2006, Schultz et al. 2008, Chabot \& Allen 2009, Chapman et al. 2009, Portnoy et al. 2010, Shivji 2010), we anticipate that limited access to trade-derived fins will soon become the primary obstacle to obtaining useful stock-specific landings data through MSA. In anticipation of this limitation, we briefly discuss the current status of the fin trade and suggest avenues to obtain samples for MSA in the future to stimulate further thought on this issue. From 1999 to 2002, one of us (S.C.C.) accessed the Hong Kong shark fin market, at the time the world's largest ( $50 \%$ of total trade volume), enabling a series of studies on the size, species composition, and nature of the global shark fin trade (e.g. Clarke et al. 2006a,b). Since then, the shark fin trade has become less centralized as it has shifted more into mainland China and traders have become more guarded in allowing access to their products, likely in response to recent shark conservation campaigns (S. C. Clarke pers. obs.). Although obtaining fin samples for MSA can be extremely difficult in this climate, we suggest there are a few directions that could be productive in the future.

Obtaining fin samples for MSA could focus on either intercepting them along trade routes or by surveying Asian markets. Market surveys could involve establishing long-term cooperative relationships with fin traders to access their products. Alternatively, it may be possible for researchers to simply purchase fins. Although the high price of fins, particularly those from sought-after species, could be an obstacle to representative sampling for MSA, it may be possible to obtain lower value fins from these species (e.g. second dorsal, anal, or pelvic fins) to reduce sample acquisition costs. Such fins are usually sold in large, mixed-species packages (S. Clarke pers. obs.), suggesting that this type of sampling would be most efficient and representative as part of a large-scale, multi-species market survey. Accessing fins in trade prior to them reaching the market may be facilitated by listing shark species that are traded in high volumes on Appendix II of the Convention on International Trade in Endangered Species (CITES). Such listings would stimulate increased inspection by customs personnel of fins crossing international borders, which could enable regular, non-destructive tissue sampling of fins for MSA as a form of permit verification. MSA is not a typical component of CITES monitoring, but probably should be, given that individual stocks can be listed, and 'nondetriment' findings to enable trade in listed species are made at the stock level. We also suggest that largescale random fin sampling programs could be developed to identify the illicit presence of CITES-listed species in shipments without CITES documentation. Unlisted species would be randomly sampled as part of such a program, which could facilitate sampling and MSA for them as well.

Although establishing routine MSA of trade-derived shark fins will not be straightforward, ongoing estimation of fin landings for all countries participating in 
shark fisheries is likely to be far more complicated, time-consuming, and expensive. We postulate that representative MSA of trade-derived shark fins remains worthy of further consideration for obtaining stock-specific trade data for sharks. This is especially true in light of recent progress in the delineation of the genetic stock structure of several shark species that are important in the fin trade, including the especially vulnerable dusky shark.

Acknowledgements. This research was funded by The Pew Charitable Trust through a grant to the Institute for Ocean Conservation Science at Stony Brook University. Sequence data were collected in the Field Museum's Pritzker Laboratory for Molecular Systematics and Evolution, operated with support from the Pritzker Foundation. Additional sequence data were collected at the Guy Harvey Research Institute with operational funds and a grant from the Save Our Seas Foundation. Funding for M.B. was provided by the Turner Fellowship Program and the Tinker Foundation.

\section{LITERATURE CITED}

Ahonen H, Hartcourt R, Stow A (2009) Nuclear and mitochondrial DNA reveals isolation of imperilled grey nurse shark populations (Carcharias taurus). Mol Ecol 18:4409-4421

Beerkircher LR, Cortés E, Shivji MS (2002) Characteristics of shark bycatch observed on pelagic longlines off the southeastern United States, 1992-2000. Mar Fish Rev 64:40-49

Bonfil R (1994) Overview of world elasmobranch fisheries. Fish Tech Pap No. 341. FAO, Rome

Bonfil R, Meyer M, Scholl MC, Johnson R and others (2005) Transoceanic migration, spatial dynamics, and population linkages of white sharks. Science 310:100-103

> Castro ALF, Stewart BS, Wilson SG, Hueter RE and others (2007) Population genetic structure of earth's largest fish, the whale shark (Rhincodon typus). Mol Ecol 16: 5183-5192

Chabot CL, Allen LG (2009) Global population structure of the tope (Galeorhinus galeus) inferred by mitochondrial control region sequence data. Mol Ecol 18:545-552

$>$ Chapman DD, Pinhal D, Shivji MS (2009) Tracking the fin trade: genetic stock identification in western Atlantic scalloped hammerhead sharks Sphyrna lewini. Endang Species Res 9:221-228

Clarke SC, Magnussen JE, Abercrombie DL, McAllister M, Shivji MS (2006a) Identification of shark species composition and proportion in the Hong Kong shark fin market based on molecular genetics and trade records. Conserv Biol 20:201-211

- Clarke SC, McAllister MK, Milner-Gulland EJ, Kirkwood GP and others (2006b) Global estimates of shark catches using trade records from commercial markets. Ecol Lett 9: 1115-1126

Clement M, Posada D, Crandall KA (2000) TCS: a computer program to estimate gene genealogies. Mol Ecol 9: $1657-1659$

Cortés E, Brooks E, Apostolaki P, Brown CA (2006) Stock assessment of dusky shark in the U.S. Atlantic and Gulf of Mexico. NMFS SE Fisheries Science Center, Panama City, FL

Davies DH, Joubert LS (1967) Age evaluation and shark tagging in South African waters 1964-65. In: Gilbert PW,
Mathewson RF, Rall DP (eds) Sharks, skates, and rays. Johns Hopkins Press, Baltimore, MD, p 111-140

Dudgeon CL, Broderick D, Ovenden JR (2009) IUCN classification zones concord with, but underestimate, the population genetic structure of the zebra shark Stegostoma fasciatum in the Indo-West Pacific. Mol Ecol 18:248-261

> Dulvy NK, Baum JK, Clarke SC and others (2008) You can swim but you can't hide: the global status and conservation of oceanic pelagic sharks and rays. Aquat Conserv 18: 459-482

> Duncan KM, Martin AP, Bowen BW, De Couet HG (2006) Global phylogeography of the scalloped hammerhead shark (Sphyrna lewini). Mol Ecol 15:2239-2251

- Excoffier L, Smouse PE, Quattro JM (1992) Analysis of molecular variance inferred from metric distances among DNA haplotypes: application to human mitochondrial DNA restriction data. Genetics 131:479-491

FAO (Food and Agriculture Organization of the United Nations) (2000) Fisheries management: 1. Conservation and management of sharks. FAO technical guidelines for responsible fisheries 4 (Supplement 1). FAO, Rome

Feldheim KA, Gruber SH, Ashley MV (2004) Reconstruction of parental microsatellite genotypes reveals female polyandry and philopatry in the lemon shark, Negaprion brevirostris. Evolution 58:2332-2342

Garber AF, Tringali MD, Franks JS (2005) Population genetic and phylogeographic structure of wahoo, Acanthocybium solandri, from the western central Atlantic and Pacific Oceans. Mar Biol 147:205-214

Heist EJ, Musick JA, Graves JE (1996) Mitochondrial DNA diversity and divergence among sharpnose sharks, Rhizoprionodon terranovae, from the Gulf of Mexico and MidAtlantic Bight. Fish Bull 94:664-668

> Hussey NE, McCarthy ID, Dudley SFJ, Mann BQ (2009) Nursery grounds, movement patterns and growth rates of dusky sharks, Carcharhinus obscurus: a long-term tag and release study in South African waters. Mar Freshw Res 60: $571-583$

ICCAT (International Commission for the Conservation of Atlantic Tunas) (2005) Report of the 2004 inter-sessional meeting of the ICCAT subcommittee on by-catches: shark stock assessment. Collect Vol Sci Pap ICCAT 58:799-890

Keeney DB, Heist EJ (2006) Worldwide phylogeography of the blacktip shark (Carcharhinus limbatus) inferred from mitochondrial DNA reveals isolation of western Atlantic populations coupled with recent Pacific dispersal. Mol Ecol 15:3669-3679

Keeney DB, Heupel MR, Hueter RE, Heist EJ (2003) Genetic heterogeneity among blacktip shark, Carcharhinus limbatus, continental nurseries along the U.S. Atlantic and Gulf of Mexico. Mar Biol 143:1039-1046

- Keeney DB, Heupel MR, Hueter RE, Heist EJ (2005) Microsatellite and mitochondrial DNA analyses of the genetic structure of blacktip shark (Carcharhinus limbatus) nurseries in the northwestern Atlantic, Gulf of Mexico, and Caribbean Sea. Mol Ecol 14:1911-1923

Kohler N (1996) NMFS cooperative shark tagging program. Shark News Newsl IUCN SSC Shark Specialist Group 7: $1-2$

Last PR, Stevens JD (1994) Sharks and rays of Australia. CSIRO, Hobart

McAuley R, Lenanton R, Chidlow J, Allison R, Heist EJ (2005) Biology and stock assessment of the thickskin (sandbar) shark, Carcharhinus plumbeus, in western Australia and further refinement of the dusky shark, Carcharhinus obscurus, stock assessment. Fisheries Research Division, Western Australian Fisheries and Marine Research La- 
boratories, North Beach, available at www.fish.wa.gov.au/ docs/frr/frr151/frr151.pdf

McDowell JR, Carlsson JEL, Graves JE (2007) Genetic analysis of the blue marlin (Makaira nigricans) stock structure in the Atlantic Ocean. Gulf Caribb Res 19:75-82

Moritz C (1994) Applications of mitochondrial DNA analysis in conservation: a critical review. Mol Ecol Notes 3: 401-411

Musick JA, Harbin MM, Compagno LJV (2004) Historical zoogeography of the Selachii. In: Carrier JC, Musick JA, Heithaus MR (eds) Biology of sharks and their relatives. CRC Press, Boca Raton, FL, p 33-78

Musick JA, Grubbs RD, Baum JK, Cortés E (2007) Carcharhinus obscurus. In: IUCN 2009. IUCN Red List of Threatened Species. Version 2009.2. Available at www.iucnredlist.org

Natanson L, Casey JG, Kohler N (1995) Age and growth estimates for the dusky shark, Carcharhinus obscurus, in the western North Atlantic Ocean. Fish Bull 93:116-126

Naylor GJP (1992) The phylogenetic relationships among requiem and hammerhead sharks - inferring phylogeny when thousands of equally most parsimonious trees result. Cladistics 8:295-318

Ovenden JR, Kashiwagi T, Broderick D, Giles J, Salini J (2009) The extent of population subdivision differs among four co-distributed shark species in the Indo-Australian archipelago. BMC Evol Biol 9:40

Pank M, Stanhope MJ, Natanson L, Kohler N, Shivji MS (2001) Rapid and simultaneous identification of body parts from the morphologically similar sharks Carcharhinus obscurus and Carcharhinus plumbeus (Carcharhinidae) using multiplex PCR. Mar Biotechnol 3:231-240

Pardini AT, Jones CS, Noble LR, Kreiser B and others (2001) Sexbiased dispersal of great white sharks. Nature 412:139-140

Portnoy D, McDowell J, Heist E, Musick J, Graves J (2010) World phylogeography and male-mediated gene flow in

Editorial responsibility: Mike Bruford,

Cardiff, UK the sandbar shark, Carcharhinus plumbeus. Mol Ecol 19: $1994-2010$

Posada D (2008) jModeltest: phylogenetic model averaging. Mol Biol Evol 25:1253-1256

Romine JG, Musick JA, Burgess GH (2009) Demographic analyses of the dusky shark, Carcharhinus obscurus, in the Northwest Atlantic incorporating hooking mortality estimates and revised reproductive parameters. Environ Biol Fishes 84:277-289

Rose DA (1996) An overview of world trade in sharks and other cartilaginous fishes. TRAFFIC International, Cambridge

Rozas J, Sánchez-DelBarrio JC, Messeguer X, Rozas R (2003) DnaSP, DNA polymorphism analyses by the coalescent and other methods. Bioinformatics 19:2496-2497

Schneider S, Roessli D, Excoffier L (2000) Arlequin ver 2.000: a software for population genetics data analysis. Genetics and Biometry Laboratory, Dept. of Anthropology and Ecology, University of Geneva

Schultz JK, Feldheim KA, Gruber SH, Ashley MV, McGovern TM, Bowen BW (2008) Global phylogeography and seascape genetics of the lemon sharks (genus Negaprion). Mol Ecol 17:5336-5348

Shivji MS (2010) DNA forensic applications in shark management and conservation. In: Carrier JC, Musick JA, Heithaus MR (eds) Sharks and their relatives II: biodiversity, adaptive physiology, and conservation. CRC Press, Boca Raton, FL, p 593-610

Simpfendorfer CA, McAuley R, Chidlow J, Unsworth P (2002) Validated age and growth of the dusky shark, Carcharhinus obscurus, from western Australian waters. Mar Freshw Res 53:567-573

Stow A, Zenger $K$, Briscoe D, Gillings $M$, Peddemors V, Otway N, Hartcourt R (2006) Isolation and genetic diversity of endangered grey nurse shark (Carcharias taurus) populations. Biol Lett 2:308-311

Submitted: September 30, 2010; Accepted: January 12, 2011 Proofs received from author(s): March 28, 2011 